\title{
Aplikasi Finger Painting Terhadap Perkembangan Motorik Halus Pada An. M Usia Prasekolah Di Desa Karang Tengah Kecamatan Tanggeung Kabupaten Cianjur
}

\author{
Ermi Sri Nuning Saputri.K \\ Universitas Muhammadiyah Sukabumi \\ E-mail: 1ermisri09@gmail.com
}

\begin{abstract}
Abstrak
Anak prasekolah adalah anak yang berusia 3 sampai 5 tahun. Permasalahan gangguan perkembangan dari tahun ketahun masih belum teratasi khususnya di Indonesia, kejadian ini dibuktikan dengan sebanyak 16\% dari anak usia dibawah lima tahun mengalami gangguan perkembangan syaraf dan otak mulai dari yang ringan sampai yang berat. Salah satu tindakan yang berperan dalam penanganan gangguan motorik halus pada anak adalah terapi finger painting. Tujuan dari penelitian ini adalah untuk mengaplikasikan finger painting terhadap perkembangan motorik halus An. M usia prasekolah. Desain penelitian ini menggunakan metode studi kasus. Partisipan yang diambil adalah satu anak yang mengalami keterlambatan perkembangan motorik halus yang berada di Desa Karang Tengah. Didapatkan data dari hari 1-2 anak masih tidak bisa menggambar dengan baik, dan hari ke 3 anak mulai dapat menggambar dengan baik. Hasil penelitian menunjukan ada peningkatan perkembangan kemampuan motorik halus anak setelah diberikan aplikasi finger painting.
\end{abstract}

Kata kunci: Anak Usia Prasekolah, Perkembangan Motorik Halus, Finger Painting

\begin{abstract}
Preschoolers are children aged 3 to 5 years. The problem of developmental disorders from year to year is still not resolved, especially in Indonesia, this incident is evidenced by as many as $16 \%$ of children under the age of five experiencing neurological and brain development disorders ranging from mild to severe. One of the actions that play a role in handling fine motor disorders in children is finger painting therapy. The purpose of this study was to apply finger painting to the fine motor development of An. M preschool age. This research design uses a case study method. The participant taken is one child who has delayed fine motor development in Karang Tengah Village. The data obtained from day 12 children still can't draw well, and on day 3 children start to be able to draw well. The results showed that there was an increase in the development of children's fine motor skills after being given the finger painting application.
\end{abstract}

Keywords: Preschool Age Children, Fine Motor Development, Finger Painting

\section{Pendahuluan}

Pertumbuhan dan perkembangan merupakan dua peristiwa yang berbeda namun sulit dipisahkan. Proses tahap perkembangan setiap anak sama yaitu merupakan hasil dari proses pematangan. Tetapi dalam pencapaiannya, setiap anak memiliki kecepatan yang berbeda. Tahap tumbuh kembang anak dibagi menjadi beberapa diantaranya adalah masa prenatal dari konsepsi sampai lahir, masa bayi dari usia 0-1 tahun, masa anak dini 1-3 tahun, masa prasekolah usia 3-6 tahun dan masa sekolah usia 6-18 tahun atau 20 tahun (Maghfuroh \& Putri, 2017). 
Pertumbuhan adalah perubahan besar yang meliputi jumlah, ukuran, atau dimensi tingkat sel, organ maupun individu yang bisa diukur dengan ukuran berat, panjang, umur, tulang, dan keseimbangan metaboliknya (Soetjaningsih \& Ranuh, 2013). Sedangkan perkembangan adalah bertambahnya kemampuan intelektual dan struktur fungsi tubuh yang lebih kompleks dalam pola yang teratur. Perkembangan ini meliputi proses diferensiasi sel, jaringan tubuh, organ dan sistem organ yang terorganisasi dan berkembang sedemikian rupa sehingga dapat memenuhi setiap fungsinya. Perkembangan juga meliputi perkembangan emosi, intelektual, dan perilaku sebagai hasil interaksi dengan lingkungan (Nurjanah, Dkk, 2017).

Perkembangan motorik merupakan suatu prubahan dalam prilaku gerak yang memperlihatkan interaksi dari kematangan makhluk dan lingkungannya. Pada manusia perkembangan motorik merupakan perubahan kemampuan gerak dari bayi smapai dewasa yang melibatkan berbagai aspek prilaku dan kemampuan gerak. Aspek perilaku dan perkembangan motorik saling saling mempengaruhi satu sama lain (Saputri, 2019).

Perkembangan motorik ini difokuskan pada proses kemampuan gerak seorang anak, sejak lahir bayi telah memulai perkembangan motoriknya yang dibutuhkan untuk berinteraksi dengan lingkungannya, dengan perkembangan kemampuan motorik anak akan berinteraksi seutuhnya dengan lingkungannya (Yanti dan Fridalni, 2020).

Data WHO pada tahun 2018, menyebutkan bahwa secara global, tercatat 52,9 juta anak yang lebih muda dari 5 tahun, 54\% anak laki-laki memiliki gangguan perkembangan, sekitar $95 \%$ dari anak-anak yang mengalami gangguan perkembangan hidup di negara dengan pendapatan rendah dan menengah. Prevalensi penyimpangan perkembangan pada anak usia dibawah 5 tahun di Indonesia yang dilaporkan WHO pada tahun 2016 adalah 7,512,6 per 100.000 populasi $(7,51 \%)$.

Berdasarkan data UNICEF (United Nations Children's Fund) pada tahun 2011, anak usia balita yang mengalami gangguan pertumbuhan dan perkembangan masih tinggi, sekitar 3 juta anak atau 27,5\% mengalami gangguan khususnya gangguan perkembangan motorik. (Farida, dkk, 2020). Laporan IDAI pada tahun 2015, dari hasil pemeriksaan pada 2634 anak dengan rentang usia 0-6 tahun ditemukan pertumbuhan dan perkembangan anak normal 53\% anak yang perkembangannya meragukan sekitar $13 \%$ dan penyimpangan perkembangan 34\% (Yanti \& Fridalni, 2020).

Sedangkan menurut Farida, Dkk (2020), permasalahan gangguan perkembangan di tengah masyarakat dari tahun ke tahun masih belum teratasi khususnya di Indonesia. Kejadian ini dibuktikan oleh jumlah balita 0-2 tahun di Indonesia sebanyak 14.228.917 jiwa, Sementara balita dengan interval umur 1-4 tahun berjumlah 19.388.791 jiwa. Di Indonesia sekitar $16 \%$ dari anak usia dibawah lima tahun mengalami gangguan perkembangan saraf dan otak mulai dari yang ringan sampai yang berat. Secara umum sekitar 5-10\% anak diperkirakan mengalami keterlambatan perkembangan namun penyebab terebut belum diketahui dengan pasti, dan secara umum di Indonesia sendiri yang mengalami gangguan keterlambatan seperti sosial, emosi, bahasa, kognitif dan perkembangan motorik diperkirakan sekitar 1-3\% pada anak umur dibawah lima tahun. Hasil penelitian perkembangan motorik pada anak usia dibawah lima tahun mengemukakan keterlambatan perkembangan motorik sebanyak $49 \%$ akibat pengetahuan ibu kurang baik dan terjadi di negara berkembang. Agar perkembangan dapat optimal harus adanya kemampuan motorik seperti motorik kasar dan motorik halus, karena dengan kemampuan motorik ini anak dapat memiliki keterampilan yang merupakan bagian dari perkembangan.

Adapun permasalahan perkembangan yang masih banyak terjadi dimasyarakat sampai saat ini salah satunya keterlambatan perkembangan motorik halus pada anak, keterlambatan ini dapat menyebabkan masalah yang begitu besar pada anak dikemudian hari, salah satunya anak menjadi tidak percaya diri, pemalu, kecemburuan terhadap anak lain juga ketergantungan. Hal ini dapat menyebabkan kesulitan pada anak saat memasuki bangku sekolah dikarenakan ketidakmampuan anak dalam bersosialisasi seperti bermain 
juga menulis. dengan rasa ketergantungan dan tidak percaya diri pada anak akan mengakibatkan penurunan prestasi dibawah kemampuan anak (Farida, Dkk, 2020).

Selain itu, keterlambatan motorik halus pada anak juga dapat disebabkan oleh kurangnya rangsangan dan stimulasi pada anak, untuk meningkatkan perkembangan motorik halus, setiap anak perlu mendapat stimulasi rutin sedini mungkin dan terus menerus pada setiap kesempatan, karena dengan kurangnya stimulasi dapat menyebabkan penyimpangan pertumbuhan dan perkembangan pada anak (Yanti dan Fridalni, 2020).

Untuk itu, melatih perkembangan motorik halus pada anak harus dimulai sejak dini karena perkembangan motorik halus merupakan hal yang sangat penting, oleh karena itu dibutuhkan kegiatan yang dapat membantu dalam proses tersebut salah satunya adalah kegiatan melukis dengan jari -jari (Finger Painting) (Farida, Dkk, 2020). Maka dari itu sebagai seorang perawat kita berperan penting dan bertanggung jawab dalam membantu anak yang mengalami gangguan perkembangan dalam kasus ini sebagai perawat kita berperan sebagai penyuluh dimana kita membantu klien dengan cara memberikan informasi mengenai upaya untuk menstimulasi perkembangan motorik halus anak usia prasekolah kepada keluarga.

Finger painting atau menggambar dengan jari merupakan teknik melukis dengan jari tangan secara langsung tanpa menggunakan bantuan alat. Jenis kegiatan ini dilakukan dengan cara mengoleskan adonan warna (bubur warna) menggunakan jari tangan diatas bidang gambar. Batasan jari yang digunakan adalah semua jari tangan, telapak tangan, sampai pergelangan tangan (Nurjanah, Dkk, 2017).

Kegiatan finger painting dapat mengembangkan ekspresi melalui media lukis dengan gerakan tangan, mengembangkan fantasi, imajinasi dan kreasi, melatih otot-otot tangan atau jari, koordinasi otot dan mata, melatih kecakapan mengkombinasikan warna, memupuk perasaan terhadap gerakan tangan dan keindahan (Maghfuroh \& Putri, 2017).

Karena kegiatan ini dapat membantu anak mengembangkan kemampuan motorik halusnya dengan melatih mata, tangan dan jari-jari tangan pada anak. Keterampilan finger painting ini merupakan koordinasi halus pada otot-otot kecil yang memainkan suatu peran utama (Maghfuroh \& Putri, 2017).

Adapun menurut peneliti terdahulu yang terkait dengan kegiatan finger painting, penelitian yang dilakukan oleh Sri Sukarini (2020) dengan jurnal yang berjudul "meningkatkan keterampilan motorik halus melalui kegiatan menggambar dengan teknik finger painting pada anak kelompok B2 di TK Negeri Pembina Bantul" berdasarkan hasil penelitian keterampilan motorik halus dapat ditingkatkan dengan kegiatan menggambar dengan teknik finger painting.

Menurut penelitian Nunung Nurjanah, Catharina Suryaningsih, Bareneo Dwi Asmara Putra finger painting merupakan suatu latihan atau keterampilan yang dapat meningkatkan kemampuan motorik halus pada anak usia prasekolah. Melihat dari berbgai data dan informasi di atas dan mengingat pentingnya kegiatan finger painting terhadap perkembangan motorik halus pada anak maka mendorong penulis untuk melakukan penelitian pada kasus tersebut yang dituangan dalam Karya Tulis Ilmiah dengan judul "Aplikasi finger painting terhadap perkembangan motorik halus An. M usia prasekolah di Desa Karangtengah Kecamatan Tanggeung Kabupaten Cianjur".

\section{Metode Penelitian}

Penelitian dengan mengunakan metode Kualitatif dengan metode pengumpulan data diantanya:

a. Wawancara

Wawancara merupakan metode dalam pengumpulan data dengan cara mewawancarai secara langsung dari responden yang diteliti, metode ini memberikan hasil secara langsung, dan dapat dilakukan apabila ingin tahu hal-hal dari responden secara mendalam serta jumlah responden sedikit. Dalam metode wawancara ini dapat 
digunakan instrumen berupa pedoman wawancara kemudian daftar periksa atau checklist (Hidayat, 2017).

Dalam metode ini peneliti melakukan anamnesis dengan fokus pertanyaan: pengkajian identitas pasien, keluhan utama pasien, riwayat kesehatan sekarang, dahulu dan keluarga, serta pola aktivitas pasien sehari-hari dan lain-lain.

b. Observasi

Observasi merupakan cara pengumpulan data dengan observasi secara langsung kepada responden yang dilakukan penelitian untuk mencari perubahan atau hal-hal yang akan diteliti. Dalam metode observasi ini, instrumen yang dapat digunakan adalah observasi, panduan pengamatan (observasi), atau lembar checklist (Hidayat, 2017). Dalam penelitian ini, peneliti menggunakan metode pengumpulan data observasi, yang meninjau langsung keadaan responden. Sehingga peneliti dapat mengetahui kondisi tempat tinggal, status kesehatan, dan keadaan psikologis responden.

c. Dokumentasi

Dokumetasi merupakan cara pengumpulan data penelitian melalui dokumen (data sekunder) seperti statistik status pemeriksaan pasien, rekam medik, laporan, dan lain-lain (Hidayat, 2017). Peneliti menggunakan pengumpulan data dengan metode studi dokumen karena dokumen memberi informasi tentang situasi yang tidak dapat diperoleh langsung melalui observasi langsung atau wawancara. Peneliti melakukan pendokumentasian asuhan keperawatan berdasarkan pokok asuhan keperawatan yaitu, pengkajian, diagnosa, intervensi, implementasi dan evaluasi keperawatan. Penelitian juga melakukan wawancara dan observasi langsung serta mendokumentasikan kegiatan dalam bentuk foto, yang dilakukan pada satu responden sesuai dengan masalah yang diambil peneliti.

\section{Hasil}

Didapatkan hasil data sebagai berikut, klien merupakan anak pertama dari dua bersaudara, saat ini klien berusia 5 tahun, kebiasaan sehari-hari klien hanya bermain gadget dirumah, klien jarang beramain dengan teman sebayanya. Pada masa pandemi ini orang tua klien mengaku cemas jika klien bermain bebas diluar rumah, sehingga orang tua lebih nyaman jika klien hanya bermain gadget dirumah.

Hal ini membuat klien tidak tertarik dengan hal lain terutama belajar selain bermain gadget, sehingga klien kurang mendapatkan stimulus yang dapat meningkatkan kemampuan motoriknya. Sedangkan pada anak usia prasekolah kegiatan di luar rumah atau pun kegiatan lain selain bermain gadget sangat dibutuhkan untuk meningkatkan kemampuan motorik halusnya. Terdapat 2 diagnosis yang muncul pada klien diantanya adalah resiko gangguan perkembangan dan defisit pengetahuan orang tua,

Dari permasalah keperawatan yang ada, penulis lebih memfokuskan untuk mengatasi resiko gangguan perkembangan sehingga perumusan rencana tindakan keperawatan dilakukan untuk meningkatkan kemampuan motorik halus anak dengan mengaplikasikan tindakan menggambar dengan metode finger painting selama 3 hari, hal ini didukung oleh klien telah kooperatif. Penulis menetapkan beberapa intervensi yaitu identifikasi kebutuhan khusus anak dan kemampuan adaptasi anak, dukung anak mengekspresikan perasaan positif, menyediakan kesempatan dan alat menggambar, melukis, dan mewarnai, ajarkan nama-nama benda dan objek dilingkungan sekitar, ajarkan cara meminta bantuan, serta bantu anak dalam memberikan stimulus menggambar.

Hasil yang didapatkan selama 3 hari pada diagnosa prioritas resiko gangguan perkembangan dadapatkan hasil hari pertama klien mengatakan mengatakan bosan dan lebih suka bermain gadget dibanding belajar menggambar, hari kedua setelah diberikan finger painting klien mengatakan ingin menggambar angsa seperti yang klien lihat di $\mathrm{You}$ Tobe, hari ketiga diberikan kembali finger painting dan kini klien mengatakan ingin 
menggambar seekor burung yang memiliki bulu yang banyak, seperti yang klien lihat di gadgetnya.

\section{Pembahasan}

Pertumbuhan merupakan perubahan besar, dalam jumlah, ukuran, atau dimensi tingkat sel, organ maupun individu yang bisa di ukur dengan ukuran berat, panjang, umur tulang, dan keseimbangan metabolik (Nurjanah, dkk, 2017). Pertumbuhan merupakan perubahan yang bersifat kuantitatif atau dapat diukur, perubahan ini meliputi perubahan ukuran tubuh dan bagiannya seperti jumlah sel, jaringan, struktur, dan sistem (Mansur, 2019).

Sedangkan Perkembangan adalah rangkaian pola perubahan yang dimulai sejak masa pembuahan dan akan terus berlanjut sepanjang rentang kehidupan individu (Nurjanah, dkk, 2017). Perkembangan adalah bertambahnya kemampuan ( skill) struktur perubahan struktur dan bentuk tubuh yang lebih kompleks, dalam pola yang teratur dan dapat diramalkan, sebagai hasil dari peroses pematangan atau maturitas (Yanti \& Fridalni, 2020).

Anak prasekolah merupakan anak yang berusia 3 hingga 6 tahun yang merupakan sosok individu, makhluk sosial kultural yang sedang mengalami suatu proses perkembangan yang sangat fundamental bagi kehidupan selanjutnya dengan memiliki sejumlah potensi dan karakteristik tertentu (Sari, 2018).

Menurut Mansur (2019), Perkembangan motorik halus setiap anak tidak selalu berjalan dengan sempurna, ada beberapa faktor yang mempengaruhi perkembangan motorik halus anak, baik internal maupun eksternal, berikut ini merupakan faktor yang mempengaruhi perkembangan motorik halus pada anak diantaranya:
a. Kondisi pra kelahiran
b. Faktor genetik
c. Kesehatan dan gizi anak pasca kelahiran
d. Intelegence Question
e. Stimulasi yang tepat
f. Pola asuh
g. Cacat fisik

Salah satu kegiatan yang dapat digunakan untuk meningkatkan kemapuan motorik halus pada anak usia prasekolah adalah kegiatan menggambar dengan metode finger painting. Finger painting atau menggambar dengan jari merupakan teknik melukis dengan jari tangan secara langsung tanpa menggunakan bantuan alat. Jenis kegiatan ini dilakukan dengan cara mengoleskan adonan warna (bubur warna) menggunakan jari tangan diatas bidang gambar. Batasan jari yang digunakan adalah semua jari tangan, telapak tangan, sampai pergelangan tangan (Nurjanah, dkk, 2017).

Adapun Langkah-langkah serta alat dan bahan yang dapat digunakan adalah Dikutip dari Sovia (2017), Adapun alat dan bahan yang diperlukan untuk bermain finger painting yaitu: Cat warna khusus finger painting, Koran, Wadah kecil untuk tempat cat (pallete), Buku gambar atau karton, Air untuk cuci tangan. Langkah-langkah bermain finger painting Tuangkan beberapa cat dengan warna berbeda cat dengan berbagai warna ke beberapa wadah, Beri alas tempat bermain cat agar tidak kotor kemana-mana dengan koran, Lalu siapkan air untuk mencuci tangan, Langkah selanjutnya ajak anak untuk mencelupkan bawah telapak jari, lalu tempelkan jari yang telah terkena cat ke karton, Untuk mencoba warna lain cuci terlebih dahulu tangan anak agar warna tidak tercampur, Biarkan anak berkreasi tentunya dengan arahan atau bantuan, Cuci tangan dan bersihkan. 


\section{Simpulan}

Dari uraian di atas dapat dilihat adanya peningkatan kemampuan motorik halus pada anak usia prasekolah setelah dilakukan tindakan finger painting, untuk itu sebagai orang tua sudah seharusnya melatih dan mengarahkan anak dalam segala aspek salah satunya perkembangan motoriknya. Indikator finger painting ini untuk anak dengan gangguan perkembangan motorik halus. selain itu kegiatan finger painting juga dapat dijadikan alternatif yang mudah untuk meningkatkan kemampuan motorik halus anak, karena metode ini merupakan metode yang mudah dan menarik.

\section{Referensi}

Aprian. (2018). Penggunaan finger painting untuk mengembangkan motorik halus anak usia 5-6 tahun di taman kanak-kanak halimatusadiah kota jambi. Jambi: UIN Sultan Thaha Saifuddin

Ariani, dkk. (2020). Optimalisasi tumbuh kembang anak dengan penyakit jantung bawaan. UB Press.

Astar, Fatmawati, dkk. (2018). Pengaruh Pelayanan Asuhan Keperawatan Terhadap Kepuasan Pasien Di Puskesmas Takalala Kabupaten Soppeng. Jurnal Of Management. Vol. 1. Nomber. (2).

Astria, nina, dkk. (2015). Penerapan metode bermain melalui kegiatan finger painting untuk meningkatkan kemampuan motorik halus. E-journal \{G PAUD Universitas Pendidikan Ganesha. Vol.3 No. 1.

Azizah. (2015). Angkringan sebagai unsur tradisional tempat interaksi sosial masyarakat perkotaan. [Skripsi Universitas Islam Negeri Hidayah Jakarta].

Dewi, Rizki. (2015). Teori Dan Konsep Tumbuh Kembang Bayi Toodler, Anak Usia Prasekolah. Nusa Media.

Farida, dkk. (2020). Pengaruh Pemberian Stimulus Seni Melukis Dengan Teknik Pointilis Terhadap Perkembangan Motorikmhalus Pada Anak Prasekolah. Jurnal Mahasiswa Kesehatan. Vol. 1. Nomber. (2). 140-150.

Indah. (2020). "Cara skrining anak dengan tabel Denver II". (http://www.google.com/amp/s/www/orami.co.id/amp/skrining-perkembangananak-dengan-tabel-denver-ii/)

Maghfuroh, lilis dan Kiki Chayaning Putri. (2017). Pengaruh Finger Painting Terhadap Perkembangan Motorik Halus Anak Usia Prasekolah Di Tk Sartika 1 Sumerguk Kecamatan Babat Lamongan. Jurnal Ilmiah Kesehatan. Vol. 10. Nomber: 1. 36-43. Magatri, Sit. (2012). Perkembangan kualitas anak usia dini. Medan: Perdana Publising Mansur, Arif R. (2019). Tumbuh kembang anak usia prasekolah. Andalas University Press. Nahriyah, Syafa'atun. (2018). Tumbuh Kembang Anak Era Digital. Jurnal pendidikan dan studi islam. Vol 4. November. (1). 
Nurjanah, Nunung, dkk. (2017). Pengaruh Finger Painting Terhadap Perkembangan Motorik Halus Anak Prasekolah Di TK At-Taqwa. Jurnal Keperawatan BSI. Vol. V. Nomber. (2).

Nursalam. (2013). Proses dan dokumentasi keperawatan, konsep dan praktek. Salemba Medika.

Perawatkitasatu. (2019). "Laporan pendahuluan askep keluarga dengan gangguan tumbuh kembang". (Https://www.perawatkitasatu.com/2019/04/laporan-pendahuluanaskep-keluarga-dengan-gangguan-tumbuh-kembang.html)

Sari, Lia P, dkk. (2018). Pengaruh senam otak terhadap peningkatan motorik halus pada anak usia 3-4 tahun di PAUD mawar tlogomas malang. Nursing news. Vol 3. No. 1.

Sari, LP. (2018). Pengaruh Senam Otak Terhadap Peningkatan Motorik Halus Pada Anak Usia 3-4 Tahun Di PAUD Mawar Tlogomas. Jurnal Nursing News. Vol. 3. No (1).

Septi, Anggraeni. (2018). "Manfaat permainan finger painting untuk anak usia dini” dalam (Http://www.anggraenisepti.com/2018/02/manfaat-permainan-finger-paintinguntuk.html?m=1)

Saurina, nia. (2016). Aplikasi deteksi dini tumbuh kembang anak usia nol hingga enam tahun berbasi anroid. Jurnal buana informatika. Vol. 7. Nomber. (1).

Sukarini, Sri. (2020). Meningkatkan keterampilan motorik halus melalui kegiatan menggambar dengan teknik finger painting pada anak kelompok B2 di TK Negeri Pembina Bantul. Jurnal Pendidikan Anak. Vol. 9. Nomber (2).

Suliati. (2016). Pengaruh Kegiatan Finger Painting Berbasis Teori Komunikasi Terhadap Keterampilan Motorik Halus Anak. E-jurnal Pendidikan anak usia dini universitas Pendidikan Ghanesa. Vol. 4. No. 2.

Sovia, yeni. (2017). "Cara membuat dan bermain finger painting untuk anak usia dini”. (hhtps://www.yenisovia.com/2017/11/cara-membuat-dan-bermain-fingerpainting.html)

Tim Pokja SDKI DPP PPNI. (2017). Standar Diagnosis Keperawatan Indonesia (SDKI): Definisi dan indikator diagnostik edisi 1 (cetakan III). Persatuan Perawat Nasional Indonesia.

Tim Pokja SDKI DPP PPNI. (2018). Standar Intervensi Keperawatan Indonesia (SIKI): Definisi dan tindakan keperawatan edisi 1 (cetakan II) Persatuan Perawat Nasional Indonesia.

Tim Pokja SDKI DPP PPNI. (2019). Standar Luaran Keperawatan Indonesia (SLKI): Definisi dan kreteria hasil keperawatan edisi 1 (cetakan II) Persatuan Perawat Nasional Indonesia. 
Volume 4, Nomor 1, Juli 2021

Yanti, Etri dan Nova Fridalni. (2020). Factor Yang Mempengaruhi Perkembangan Motorik Anak Usia Prasekolah. Jurnal Kesehatan Medica Santika. Vol. II. Nomber: (2). 